\title{
4 modalities of periodontal treatment compared over 5 years*
}

\author{
Ramfjord SP, Caffesse RG, Morrison EC, Hill RW, Kerry G.J. Appleberv EA. \\ Nissle $R R$ and Siults DL: 4 modalities of periodontal treament compard over \\ 5 vears. J Clin Periodontol 1987; 14: 445-452.
}

Abstract. The purpose of the prescnt study was to assess in a clinical trial over 5 years the results following 4 different modalitics of periodontal therapy (pocket elimination or reduction surgery, modified Widman flap surgery, subgingival curettage, and scaling and rool planing). 90 patients were treated. The treatment methods were applied on a random basis to each of the 4 quadrants of the dentition. The patients were given professional tooth cleaning and oral hygiene instructions cvery 3 months. Pocket depth and attachment levels werc scored once a year. 72 patients completed the 5 years of observation. Both patient means for pocket depth and attachment level as well as \% distribution of siles with loss of attachment $\geq 2 \mathrm{~mm}$ and $\geq 3 \mathrm{~mm}$ were compared.

For $1-3 \mathrm{~mm}$ probing depth, scaling and root planing. as well as subgingival curettage led to significantly less atachment loss than pocket elimination and modified Widman flap surgery. For $46 \mathrm{~mm}$ pockets, scaling and root planing and curettage had better attachment results than pocket elimination surgery. For the $7 \cdots 12 \mathrm{~mm}$ pockets, there was no statistically significant difference among the results following the various procedures.
Key words: Scaling - root planing - curettage - product elimination - modified Widman flap - probing depth - attachment level - tooth loss - furentions.

Accepted for publication 25 August 1986
In a previous paper (Hill et al. 1981). 2year results from a clinical trial comparing surgical and non-surgical techniques for treatment of moderate $\mathrm{to}$ advanced periodontitis were published. The clinical results following the 4 difterent procedures were fairly similar. Several other investigators (Pihlstrom ct al. 1981. Lindhe et a1. 1982, Lindhe et al. 1984, Isidor et al. 1984) have also compared results following surgical and non-surgical periodontal therapy over as much as $6 \frac{1}{2}$ years (Pihlstrom et at. 1984 and reported that only minor differences ocurred between methods with respect to probing depth and attachthent level alterations. With the notoriously slow process of adult-type periodontitis even in the absence of periodontal therapy (Lindhe et a!. 1983). and the limitations of probing in discerning small differences, the focus of interest in clinical trials involving various modalities of periodontal treatment should be more and more directed toward long-term observations involving as many patients as possible. If the

* This study was supported by Grant DDE 02731 . average annual loss of attachment for untreated cases of periodontitis is 0.2 mm (Lindhe et a]. 1983). a crude instrument such as a probe with a unit scale of I mur ohvously can only record irends based on numerous measurements over a long period of tine.

It appears from previous observations that results of periodontal therapy become fairly stable over 5 years of observation (Knowles e! al. 1979, Lindhe \& Nyman 1984) with measurable changes only for very few teeth. It also becomes very difticuli to keep an experimental group together for more than linat length of time for welt-controlled. standardized care 5 years of observation should enable us to spol trends in behaviout of regularly repeated measurements including absorption of unavoidable errots.

\section{Material and Methods}

The types of patients and methods of treatment were reported in a previous paper (Hill et al, 1981), and will only be sunmarized here. 90 subjects with moderate to advanced periodontitis were treated. Following initial examin- ation, they were treated with scaling. root planing and instruction in oral hygiene (hygiene phase of therapy) by a dental hygienist. Occlusal adjustment was subsecuently performed by a periodontist. 4 modalities of periodontal treatment were randomized and per. formed by a periodontist. Thus, each of the 4 quadrants had an equal chance of receiving any one of the experimental procedures. The treatments were: (1) surgical pocker elimination (Prichard 1972) including bont surgery, or pocket reduction for the very deep pockets; (2) modified Widman flap surgery (Ramljord \& Nissle 1974); (3) subgingival curettage (Ramfjord \& Ash 1979): (4) scaling and root planing only (Ramfjord \& Ash 1979). All treatment procedures were performed under local anesthesia. The patients were recalled for prophylaxis once a week for 4 weeks post-surgically, and later once every 3 months for the 5 years of the study. The patients were reexamined 1 month after completion of the hygienic phase of treatment, and then yearly after the experimental surgical treatments. These re-examinations werc performed 3 months after the last prophylaxis. of 
the 90 initial patients, 72 completed the 5 years of follow up.

Some pockets with overt bleeding and/or pus secretions when seen by the periodontist for annual evaluation were retreated by a periodontist during the maintenance phase. The modality of retreatment was left to the judgement of the periodontist, but in most instances. scaling and rool planing with or without ancesthesia was carried out.

\section{Results \\ Probing pocket depth and clinical attachment level}

In order to keep the lindings in perspeclive with the reported 2-year otservations (Hill of al. 1981), some of the previously published data (Hill et al. 1981 ) are included in the present report.

The pockets were grouped into 3 classes at the intial examination: (i) 1 $10.3 \mathrm{~mm}$ decp llormal depth): (2) 4 10 $6 \mathrm{~mm}$ (moderate neriodontitis): (3) $\geq 7$ mm deep ladvanced periodontiris).

Inilial probing depth and attatchmen1 levels were used ats baseline in order to assess the changes which oceurred following the various treatments over the 5 years. Palient means for probing pocket depths and clinical attachment. levels within each category were used for the statistical tabulations. All of the teoth were included. and if a tooth was lost during the treatment. the measurements for that tooth were included until the tooth was lost. For parametric statistic evaluations, it was felt that the bitsic unit was the patient rather than the single toosh. or the single pochet. However. for it numericial evaluation of pockets with a certain amount of loss or gain, ons of changes were calculated. These changes will also bo considered in this paper in an attempt 10 gain as much clinically applicatele information as possible. This inlormation is import.ant to the clinician. since it relates to changes in attichment levels for special itesll and modalities ol treatment.

The variations in depth for $1-3 \mathrm{~mm}$ (Class I) pockets were small (Table 1). Although some of the differences were signilicant statistically because of a Jarge number ol subjects and small standard deviations. they seemed insignificant from a clinical point of view. They appeared mainly at the Ist year followup examination. After the second year, following the various modalities of treatment, there were no significant differences in this category of pocket. However. a slight deepening of the shatlow products gradually occurred for all modalities of treatment when compared to the baseline data.

Of greater interest was the gradual loss of attachment that continued during the 5 years of treatment and maintenance for the Class I (normal) pockets (Table 2). Part of this loss was apparently the resull of the initial treatment (Ist year follow-up). where the loss lollowing scaling and curetage was less than following the other surgical treatments. Also, there was al farly similar loss of attachment during the maintenance phase for all of the treatment groups, bu even at the 5th year. the curettage and scaling groups showed a more favorable attachment response than the flap surgery groups, although the dilferences were too small to be of clinical significance.

Pocket reduction for Class II (moderate periodontitis) (Table 3) was greater

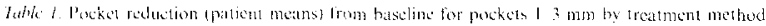

\begin{tabular}{|c|c|c|c|c|c|c|c|c|c|c|c|c|c|c|c|c|c|c|}
\hline & 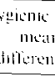 & 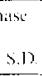 & Truatment & $x$ & $\begin{array}{l}\text { lst year } \\
\text { moth } \\
\text { ditherence }\end{array}$ & $S .1)$ & $A$ & $\begin{array}{l}\text { Ind veat } \\
\text { mean } \\
\text { difference }\end{array}$ & $5.1)$ & 1 & $\begin{array}{l}\text { 3rd Year } \\
\text { mean } \\
\text { dipterence }\end{array}$ & S.I) & 1 & $\begin{array}{l}\text { 4th year } \\
\text { mudan } \\
\text { dillereme }\end{array}$ & $5,10$. & $N$ & $\begin{array}{l}\text { Sth year } \\
\text { mears } \\
\text { differenes }\end{array}$ & $\begin{array}{l}5.0 . \\
5.0 .\end{array}$ \\
\hline (1) & 0.17 & 0.32 & 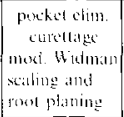 & $\begin{array}{l}x y \\
x y \\
x^{\prime} \\
x^{4}\end{array}$ & 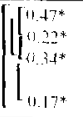 & $\begin{array}{l}0.311 \\
0.311 \\
0.32 \\
0.33\end{array}$ & $\begin{array}{l}80 \\
80 \\
801 \\
s 0\end{array}$ & {$\left[\begin{array}{c}{\left[\begin{array}{l}11.23^{*} \\
0.05 \\
0.19\end{array}\right.} \\
0.114\end{array}\right.$} & $\begin{array}{l}16.33 \\
0.34 \\
0.46 \\
0.34\end{array}$ & $\begin{array}{l}83 \\
83 \\
53 \\
83\end{array}$ & $\begin{array}{c}0.05 \\
-0.117^{*} \\
-0.00 \\
-0.118\end{array}$ & $\begin{array}{l}0.37 \\
0.31 \\
0.35 \\
0.40\end{array}$ & $\begin{array}{l}75 \\
75 \\
75 \\
75\end{array}$ & {$\left[\begin{array}{c}-0.02 \\
-0.12 * \\
-0.07 \\
-0.13^{*}\end{array}\right.$} & $\begin{array}{r}0.35 \\
* 0.30 \\
0.35 \\
+0.39\end{array}$ & $\begin{array}{l}72 \\
72 \\
72 \\
72\end{array}$ & $\begin{array}{l}-0.003 \\
-0.12^{*} \\
-0.15 * \\
-01.14 *\end{array}$ & $\begin{array}{l}0.31 \\
0.39 \\
0.30 \\
0.30\end{array}$ \\
\hline & $101 \%$ & mand & & \multicolumn{3}{|c|}{$\begin{array}{l}1.10 .272 \\
10.06 \% 1\end{array}$} & \multicolumn{3}{|c|}{$\begin{array}{l}1-4.2304 \\
1\end{array}$} & \multicolumn{3}{|c|}{$\begin{array}{l}{[\because 3.3 \times 39} \\
p<016592\end{array}$} & \multicolumn{3}{|c|}{$\begin{array}{l}1-2.1195 \\
100.69) 7 x\end{array}$} & \multicolumn{3}{|c|}{$\begin{array}{l}\mathrm{J} \cdots 20947 \\
p<0.1611\end{array}$} \\
\hline
\end{tabular}

Signilican dillerence

hementen malks

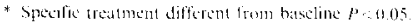

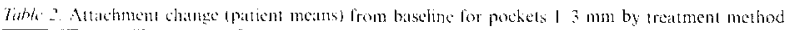

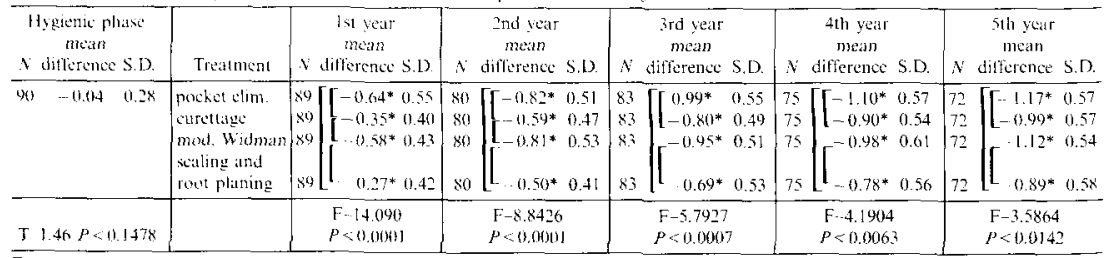

Similicini difference

1 between meins:

* Specilir treatment diterest trom bascline $p=0.015$. 
Iath 3. Pocket reduction (patient means) from baseline for pockets $4.6 \mathrm{~mm}$ by treatment method

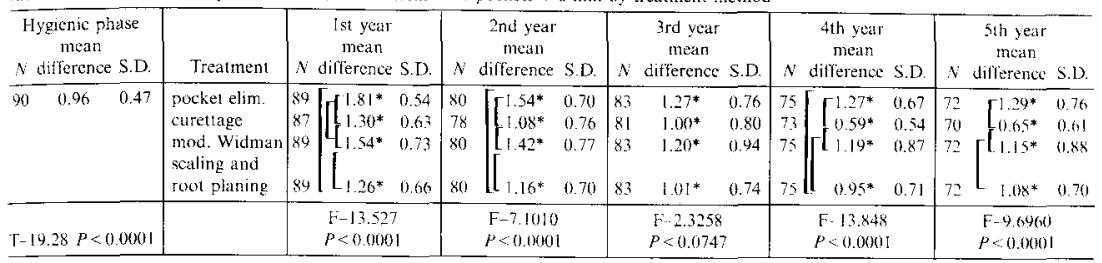

Significant difference

between means

* Specific treatment different from baseline $P<0.05$

1 ycar following both types of tiap surgerics than following curettage or scaling. 5 years later, the same trend prevailed. with significantly more reduction following pocket elimination surgery than following curettage. The pocket reduction following scaling was similar to the reduction following open surgical treatments and significantly greater than following curettage. From a clinical standpoint, the differences were small lor all of the methods. However. the pockets were reduced significantly from the baseline.

The attachment level response for Class II pockets (pocket depth $4-6 \mathrm{~mm}$ ) 1 year after treatment was significantly better for scaling and for curellage than for both pocket elimination and modjlied Widman hap surgeries (Table 4). This trend was sustaned over the 5 years. although there was at stight loss of attachnent following all modalities of treatment. The greatest loss was following pocket elimmation surgery. The loss seemed to oceur mainly during the maintenance phase, although it apparently become statbilized after the 3 rd year.

For the deep pockets, $\geq 7 \mathrm{~mm}$ (Class III). there was a considerable reduction in pocket depth following the hygienic phase, and even greater 1 year following the various treatment modalities. The greatest reduction occurred following pocket elimination or reduction surgery and the least following scaling (Table 5). For all methods, the pocket reduetion still remaited significant after 5 years. However. the differences among the methods of treatment were small and not statistically significant.

There was a gain of clinical atlachment following all 4 methods of treatment for the Class III pockets ( $\geq 7 \mathrm{~mm})$ (Table 6). There was, however, no statistically significant difference anong the methods during the 5 years of observation. At 5 years of mantenance, only curettage and scaling showed a statisticalty significant gain of attachment compared to the baseline data. The gain observed in the other 2 groups wats similar.

\section{Frequency distribution of sites with gain or loss of clisical attachment}

The frequency distribution of sites gaining or losing $2 \mathrm{~mm}$ or nore and 3 mm or more of clinical attachment trom baseline to year 5 was related to modality of treatment (Tabics 7,8 ). The sites with pocket depth of $13 \mathrm{~mm}$ (Class 1) had the highest frequency of atlachment loss both $\geq 2 \mathrm{~mm}$ and $\geq 3$ $\mathrm{mm}$, and a higher frequency of attachment loss for surgical procedures than for either currettage or scaling and root planing. Gains in this category were practically non-existent, and almosi $90 \%$ of the treated sites were recorded as unaltered when changes of $\geq 3 \mathrm{~mm}$ were used as the basis for the counts. When pockets of 4-6 mm (Class II) were considered (Tabies 7.8), a higher $\%$ of attachment losers than gainers still

Tahle 4. Altadment change (patient muans) from batseline for pockets 4-6 mon by treatmont method

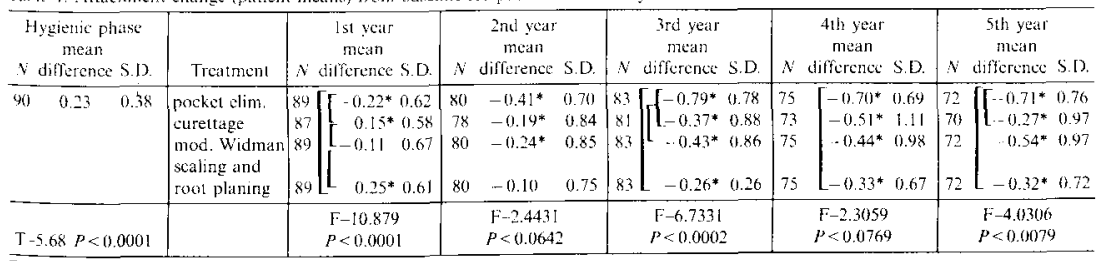

\footnotetext{
Significant difference

between means

* Specific treatment different from baseline $P<0.05$.
} 
Table 5. Pocket reduction (palient means! from baseline for pockets... 7 mm by trealment method

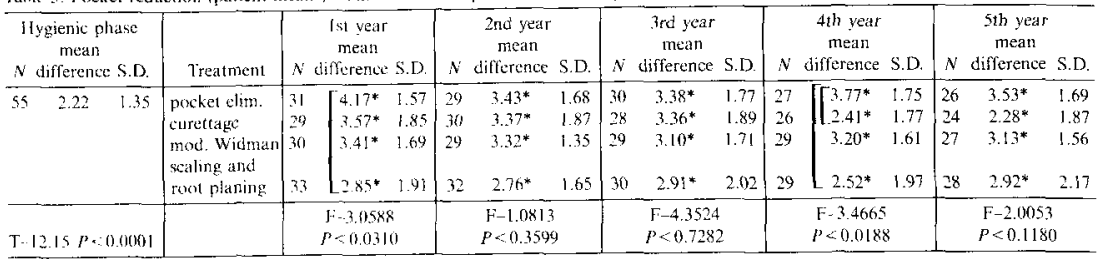

Signiticatul diflerence

hetween means

* Specilic treatment deferent from belseline $p<0.05$.

Tath 6 . Atactument diange (patient means) from baseline for pockets $77 \mathrm{~mm}$ by areatment method

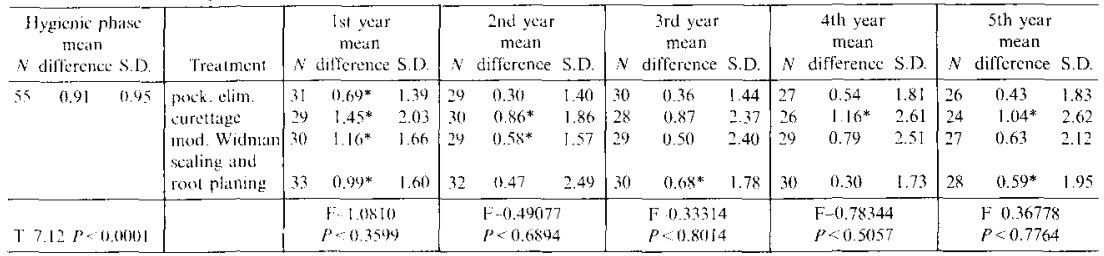

* Specilie tratment diflerent frum bisuline $P<0.05$

appeared, hut the advantage for curettage and scaling with root planing silti: was less noticeable thin for the $1-3$ nim pockets. If, however, a vitriation of $\geq 2$ mm was used for the cut-ofi point, sealing and root planing had a higher $\% / 4$ of attachment gainers than any of the other procedures, and highor than curetage, which was not the case when mean values were considered (Table 4). These differences however, were small and the $\%$ of sites was very similat for all of the 4 procedures. For Class III porkets, $(\geq 7 \mathrm{~mm})$. there were more sites which gained atlichment than lost. Curettage had the highest $\%$ of both of attachment gain and loss, while pocket elimination showed the most stable results. However. the irequency distribution data should be considered with caution, since sofew sites were included. However. it is worth noticing that attachment loses of $\geq 2$ or of $\geq 3 \mathrm{~mm}$ were relatively rare ${ }^{2}$. This indicates that very few sites with pocket depth of $\geq 7$ mm, regardless of nethod of treatment. lost attachment of 2 mon or more over 5 years.

\section{Loss of teeth}

Of the original 90 patients with 240 ! teeth, 28 teeth were lost. 72 patients with
1881 teeth initially, completed the 5year study. They lost a total of 22 teeth (3 during surgery, I during the Ist year of maintenance, 0 during the 2 nd year, I0 during the 3 rd year, 3 during the $4 \mathrm{th}$ year, and 5 during the 5 th year). 17 of these teeth were lost for periodontal reasons, and 16 of the 17 teeth had furcation involvement at baseline. Thus, less than $1 \%$ of the trated leeth were lost for periodontal reasons during the 5 years. Of these 17 teeth, 5 had been treated originally with pocket elimination, 4 with curettage, 6 with modified Widman flap, and 2 with scaling and root planing. 5 teeth were extracted for non-periodontal reasons.

Tahle 7 . Frequeney distribution of sites gaining or losing $2 \mathrm{~mm}$ of more of clinical attachment alter 5 years according to treatment and initial probing depin

\begin{tabular}{|c|c|c|c|c|c|c|c|c|c|c|c|c|}
\hline & \multicolumn{4}{|c|}{$[-3 \mathrm{~mm}]$} & \multicolumn{4}{|c|}{$4-6 \mathrm{~mm}$} & \multicolumn{4}{|c|}{$7 \ldots 12 \mathrm{~mm}$} \\
\hline & $N$ & gain & same & loss & $N$ & gain & same & loss & $\bar{N}$ & gain & same & loss \\
\hline pocket elmination & 1497 & $1 \mathrm{k}$ & 908 & 571 & 772 & $5 !$ & 495 & 226 & 65 & 12 & 46 & 7 \\
\hline \multirow[t]{2}{*}{ curettage } & {$[61]$} & 22 & 1048 & 541 & 659 & 60) & 450 & 149 & 55 & 18 & 31 & 6 \\
\hline & & $1.4^{1 / 0}$ & $65.1 \%$ & $33.6 \%$ & & $9.1 \%$ & $68.3 \%$ & $22.6 \%$ & & $32.7 \%$ & $56.4 \%$ & $10.9 \%$ \\
\hline modified Widman flap & 15.54 & 18 & $980^{\circ}$ & 550 & 649 & 46 & 422 & 181 & $6 ?$ & 14 & 43 & 5 \\
\hline scaling and root planing & & $1.6 \%$ & $68.1 \%$ & $30.3 \%$ & & $11.5 \%$ & $67.4 \%$ & $21.1 \%$ & & $29.5 \%$ & $55.7 \%$ & $14.8 \%$ \\
\hline
\end{tabular}


Tahle \&. Frequency distribution of sires gaining or losing $3 \mathrm{~mm}$ or more of climical attachment after 5 years accordmg to ireatmem and initial probing depth

\begin{tabular}{|c|c|c|c|c|c|c|c|c|c|c|c|c|}
\hline & \multicolumn{4}{|c|}{$1-3 \mathrm{~mm}$} & \multicolumn{4}{|c|}{$4-6 \mathrm{~nm}$} & \multicolumn{4}{|c|}{$712 \mathrm{mmis}$} \\
\hline & $N$ & gain & same & loss & $N$ & gain & siame & foss & $N$ & gain & satme & loss \\
\hline pocket elimination & 1497 & 4 & 1288 & 205 & 772 & 14 & 684 & 74 & 6.5 & 5 & $5 y$ & 1 \\
\hline \multirow[t]{2}{*}{ curettage } & $16: 1$ & 4 & 1441 & 166 & 659 & 18 & 588 & 53 & 55 & (1) & 42 & 4 \\
\hline & & $0.2 \%$ & $89.4 \%$ & $10.3 \%$ & & $2.7 \%$ & $89.2^{\pi}$ & $8.0 \%$ & & $16.4 \%$ & $764 \%$ & $7.3 \%$ \\
\hline modified Widman flap & 1554 & 3 & 1.359 & 192 & 649 & 12 & 569 & 68 & 62 & 7 & 52 & 3 \\
\hline scaling and root planing & & $0.2 \%$ & $90.6 \%$ & $9.2 \%$ & & $2.71 / 4$ & $89.2 \%$ & $8.1 \%$ & & $14.8^{t} \cdot \mathrm{t}$ & $80.3 \%$ & $4.9^{\%} \%$ \\
\hline
\end{tabular}

\section{Retreatment}

When bleeding and pus secretion following nild provocation occurred 2-? weeks after prophylaxis, the periodontist decided what teeth to retreat and which modality of retreatment to use. Flap surgery was not performed in quadrants which had been treated with curetiage or scaling alone. Some teeth with overt bleeding tendency but without pus were also retreated. Some teeth with apparently hopeless furcation involvement were not relreated. A total of 101 teeth in 24 patients were retreated. The original treatment of these teeth had been:

surgical pocket elimination - 16 teeth;

curettage - 20 teeth;

modified Widman flap - 21 leeth:

scaling and root planing - 44 teeth.

7 teeth in 2 patients werc retreated with modified Widman llap stagery: all of the of hers were retreated with scaling and root planing, with or without curetlage and usually under local anesthesia.

Ol the retreated 101 teeth, only 2 were subsequently lost. I of these teeth had originally had surgical pocket climination: the other had had curettage. and they werc both retroated with scaling and curet tage.

\section{Discussion}

The gridual loss of atlachment over itme for sites with shallow pockets, rerardless of initial treatment is a disturring but common observation (Hill et 1. 1981. Pihlstrom et al. 1981, Lindhe, t al. 1982. Isidor et al. 1984. Knowles 1 al. 1979). It has been suggested (Lindte et al. 1982) that this phenomenon ady be a consequence of the frequent nechanical disturbance of the marginal atlachment apparatus during the repeated recalt sessions. However. 1 yeat after treatment, there was a significantly greater loss for pockel elimintition and modified Widman flap. Most of these differences were mantained over 5 ycars, indicating some influence of the modality of treatment (Table 2). The loss continued during the 5 years, but the inilial differences between the treatmest groups became smaller over time. This maty indicate that in addition to an initial loss related to treatment, ther: was a graduat loss during the maintenance phase. The poche depth stayed close 10 baseline from years $3-5$ (Table 1). indicating that the attachment loss abserved was acompanied by gingival recession. I1 was shown by Olexary e1 a!. (1971) that most gingival rectsions occured in patients with effecient oral hygienc. and thas at mechatical effect of oral hygiene procedures may be suspeeted. A pretiminary comparison of plaque indices and loss of atachment for these shatlow pockets indicated that the loss of attachment was nol greater with plactue index (1) than with plaque index or 2. Which would tend to rulc out recession liom overealous toothbrustiing as a cance of the loss. Datil related to plaque scores will be reported in a separate paper. This loss of clinical atachment for shallow pockets during treatment and mainfoname apperirs to occur at a faster rate than the common loss associated with aging in well-cared for populations (Suomi et al. 1971, Loe et al. 1978). Over the vears, thete appears to be an caqualization process of gingival height taking place after periodontal treatment. This equalization has also been pointed out by Rosling et al. (1976) for intrabony lesions. This natural tendency for recontouring and rebound nity cxplain some of the recession ascociated will shallow crevices, sinee they initially had the leatst lose of attaclunent. However, from this and long-term studies (lindhe et al 1982 . Batdersten et al. 1984), it appeals that the minute loss of attachment in shallow pocket does not represent a threat to lte fut ure maintenane of the dentition.

The magnitude of poeket reduction for $4.6 \mathrm{~mm}$ pockets (Table 3) varied significantly according to the method of ireatment for the first 2 years posioperatively. However after 5 years. there was no difference in reduction al. ter scaling compared with the reduction after pocket elimination surgery. and some of the differences which were statistically significant appeared to be too small to be of any clinical significance. Afthough the pockets were significantly reduced compared to baseline. after 5 years, the reduction was minimal beyond that which occurred as a result of the initial, presurgical hygieric phase of treatment. When at tachment levels were considered for the $46 \mathrm{~mm}$ pockets (Table 4), the long-term effect was a slight loss of attachment. This loss of attachment was significantly more pronounced for pocket elimination surgery than for the curettage and the scaling procedures. These findings differ from what were reported in a previous study (Knowles et al. 1979), and a further examination of the data reveatled that in the present study, the majority of the pockets in the $46 \mathrm{~mm}$ class was $4 \mathrm{~mm}$, while in the other study (Knowles et al. 1979), there was in this probing depth class a much higher $\%$ of $6 \mathrm{~mm}$ deep pockets. This difference in response to various treatment modalities related to pocket depth has been discussed in detail in a recent paper by Lindhe et al. 
(1982). A slight additional attachment loss (Table 4) appeared in this pocket depth class after 5 years for all of the treatment modalities. It is important to note that the 5-year effects on the attachment levels for 4-6 mm pockers were almost identical for curetlage and for scaling. Attachment level responses for scating and for curetlige for these pockets were significantly better than for pucket elimination surgery. Since scaling and root planing are basic procedures for all periodontal therapy, and gave results that were as good of betler than for surgical techniques for $4.6 \mathrm{~mm}$ pockets. scaling and root planing appear to be the Ireatment of choice for siles with $46 \mathrm{~mm}$ deep pockets. When access for effective scating cannol be gained withour surgery. as in the presence of furcation involvement, flap susgery for access is onviously indicated. Similar or ever hetter results, following scoling in puckels of this deph have been reported over 6\% years by Pihlstrom et al. (1984). They reported significant gain of artactiment alter scaling in sites with $4.6 \mathrm{mn}$ d deep pockets for the entirs period of observation. The atuchment lewck for the deep pockets (Class [II $\geq 7$ mm) were maintained above the batseline level for all of the treament methods witio no significant difference among them (Table 6). Chunges in allachment levels from yearto-yeal were very small as reported by athers (Pihlstrom el al. 1984. Knowles st al. 1979) This lend on smilar results from the variots provedures tend to bs: at sirnase with a commonly explested belite that stalieng and roul planing ate improper prowodures lo use in the treatment of deep porkets. Frowever, the present results seem to contirm finding by Badersten et atl. (1984) for singleronted tectit.

$h$ is becoming increasingly evident that complete removal of all calculus and tesidaal plaque from roen surfaces exposed in deep periodontal pockets is not commonly antained (Caftesse en al. 1985. Eaton et al 1985, Rabbani et al. 1981).

Data from research and clinical experience indicate that less deposits are left behind when roor planing is done after flap elevition than after"non-surgical" subgingival sealing. The fact that in this study, 44 teeth had to be retreated in the quadrants that initibliy had been scaled and root planed compared with about 20 for the other treatment methods, may also be taken as an indi- cation that removal of accretions was less successful following scaling than following the other methods. However, the longitudinat results of scaling were as good as for the other procedures with regard to maintenance of attachment level and prevention of loss of teeth. Furthermore, the retreatment by scaling was highly successiul in arresting the progress of the attachment loss for practically all of the retreated teeth. The loss of teeth was lower in this study thar in previous studies where no retreatment by the periodontist was performed exeept for treatment of abscesses (Know(es et al. 1979). It was also interesting to note that 16 of the 17 teeth lost from periodontal disease had furcation involvement. This contirms the assumption that the prognobis for single-rooted teeth is better than for teeth with furcation involvement.

The well-known problems associated with less than perfect reproducibility of probing pockel measurements nakes at $\%$ comparison of loss or gain or altachment tinted with anavoidable errors. especially for the deep pockets. The chances for making errors decrease as the level of tolerance increases. but such errors may ncour even at $3 \mathrm{~mm}$ levels. This makes standardization of the error diflicult, and one can never property delermine how many apparent "gains" or "losses" were in fact measurement errors.

It should the understood that the results listed in Tables 7 and 8 do not indicate that the sites presented under "samc" had the xame motasurements each time: only that the variations were less than ? nm. Even if the measure ments were the same, the atachment levels may have shown variations due to the inherent srors in the usc of the probe. It should therelore be acknowledged that at the present time we can only measure trends of at tachment level changes.

Speculations regarding time requirements for the various procedures cannot be answered by data from this stady. All of the patients received initial scaling and instruction in oral hygicne by a dental hygienist who spent from 5 to 8 h with each patient. Then, the periodontist was allotted an average of $3 \%$ $h$ to each quadrant for the treatment. regardless of which procedure he was scheduled to perform.

Thus, in this study, there was no difference in time spent for each procedure. If one were to save time doing surgery, compared with scaling and root planing alone, the surgery would have to be done without prescaling in the numerous shallow pockets where the results of scaling alone are often better than after surgery (Pihlstrom et al. 1984). As a consequence, the most sensible clinical approach seems to be scaling and instruction by a hygienist, with reexamination 4-6 weeks later by the dentist. If there is no bleeding from the bottom of the pocket with gentle probing and no pus an be provoked. it can be assumed that the progress of the disease is arrested and the area is ready for mantenance care. If the site does not heal, and blecding and/or pus can be provoked, the dentist must decide what procedure to use to clean that particular root surface. This will depend on access. especially for furcations which are usually more easy to reach during flap surgety than during "non-surgical" subgingival scaling. Deliberate soft-tissue curettage does not seem to enhance the results of scaling or root planing.

Unquestionably, flap elevation will lacilitale access to the root surfaces with furcation involvement or tortuous deep pockets and should be used at the discression of the operator. However, emphasis should be placed on thorough scaling and root planing initially and at the time of surgery. It also appears that retreatment (with or without surgery) should be a routine consideration beyond the "rectill prophylaxis" or professional tooth cleaning during the maintenance phase or therapy. Mechanical perioduntal therapy cantrot be standardized as drug prescriptions, and the results of elinical trials will only indicate probable outcome of various treatments when performed under the standardiaed conditions of the trial, and with personnel with similas training.

\section{Conclusions}

Scaling and root planing was the treatment of choice for periodontal pockets of $\geq 6 \mathrm{~mm}$, provided hereby proper access to the root surface could be obtained. For pockets of $\geq 7 \mathrm{~mm}$, the results were similar for all of the 4 methods of treatment examined. There was no additional benefit from curettage over scaling and root planing Maintenance care should include retreatment of pockets with persistant pus 
secretion and/or bleeding. Regardless of the modality of treatment. furcation involvement was the greatest hazard in the prognosis. Retreatment was needed more often after scaling and root planing than after the other procedures. but with additional scaling, the results were as good as for any other procedure.

\section{Zusammentassung}

Ein 5.Juherwergleth zwischen 4 Modahialen der Parodomalbehandlung

Mit der hier vorliegenden Studie wurde beahsichtigt, die Resultate der folgender 4 Modalitäten parodontaler Therapie (Tascheneliminatjons- oder -reduktionschirurgic, dic Technik des modilizierten Widmanlippens, subgingivate Küretalge und Zahnsteinendermung mil Wurzelglitlung) während cines s lahre andatuernden klinischen Versuches au hesting. men. so Patjenten wurden beh:andelt. Dic Beshandlungsmethoden wurden zufillige für ja2. den der 4 Gebissquadranten bestimnat ln jedem 3. Versuchsmonal wurden dic Zühne der Pitienten professionell gereinigl. DHe Tiefe de Taschen und die Attachmentmiveius warden enmal jährlich beureill. 72 Palienten standen wilhrend def gesamten Bibstullumuszcit zur Verfügung. Sowothl dic Mills werk Jer Taschenticlen, der $\Lambda$ ttachmentuiviatus als atuh dic prozentuale verteilung der "Siturn" mil At1achmentverlusten von $\geq 2$ mm und $\geq 3$ mon wurden mileinander vergliches. Bei $1-3 \mathrm{~mm}$ Sondicrungstiefe fijhten snowhl Zahnsteincenternume und Wurzelybitlumg als aluch dis subgnguvale Küretlage gh signilikant weniger Altachmentverlust wis die Ta. chencliminaten und die modilizicte Wikt-

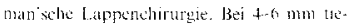
len Tathen hact心 Zahnstementernung und

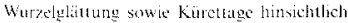

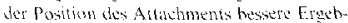
nisse als die chirurgische Taschenelimination. Baid den? I I mu Jalschen wurden keine statistisch abgesicherten Jntersihieds rwischen den Resultaten der verselvedenter Behandlumesmodillitiong getsehen.

\section{Résumé}

Traitement parodonal: comparaison de 4 modes de raitement sur 5 ans

Le but du présent travail était d évaluer pendant 5 ans par une étude clinique les resultats ubtenus par traitement parodontal suivant 4 rindes de traitement différents (élimination ou reduction chirurgicale des poches. opération a lambeau de Widman modifice, curcta- ge sous-gingival et détartrage avec surfacage radiculaire). Le traitement a porté sur 90 patients. Pour chacun des $\mathbf{4}$ quadrants de la bouche. les methodes de traitement appliquées ont été choisies au hasèrd. Les patients reevaient tous les 3 mois un nethoyage denlaire professionnel at des instructions dhygiene bucco-dentaire. Les observations ont pu otre menées sur les 5 anncos chez 72 pa- lients. Les valeurs moyennes de la profondeur des poches et du nivea de latiache par patient et la distribution de lréquence des localisations présentant une perte dattactie de $\geq 2 \mathrm{~mm}$ et $\geq 3 \mathrm{~mm}$ ont éti comparés. Pour les profondeurs de sondage de $13 \mathrm{~mm}$. le detartrage avec surfilcige radiculatire. amsi que le curetage sous-gingivil résultaicm en une perte dattache significativement moins

\section{Reterences}

Badersten, A. Nilweus. R. \& Egelberg, 3. (1984) Jffect of motr-surgical periodontal llerapy.

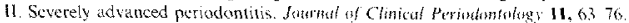

Caffesse. R. G. Sweeney. P. L. \& Smith. B. A. 19986) Scaling and roul platuing with and

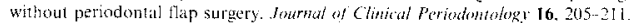

Etion. K. A. Kieser. J. B. \& Daties, R. M. (1985) The removal of root surface deposits. Jommat of Clinical Poriodontolog! 12, $141 \quad 152$.

Hill, R. W., Ramfjord. S. P. Morrison. E. C. Appleberry, F. A. Cuflesse. R. G. Kerry G. I. \& Nissle. R. R (1981) Four types of periodontal treatment compared over two yeurs.

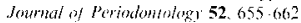

] sidor. F.. Karring. T. \& Atstrom, R. (1984) The thect of root plining as compared to that of surgical treatment. Jommal of Clincal Periedemtolog 11.669 68 I

Knowles, J. W. Burgett. F. G., Morrism. E. C.. Nissle. R. R.. Shick, R. A. \& Ramfjord, S. P. (1979) Results of periodontal treatment related to pocket depth and atlichment level: Fight years. Juarnal of Pertodontology. 50. 225-233.

Lindh: J., Westlett. F.. Nyman, S.. Socransky, S. S.. Heil, L. \& Branthall, G. (1982) J [ealing following surgicilinon-surgical treatment of periodontal disedse. A cinnical study. Joumal of Clmicat Periodontology $9,115-128$.

Lindhe, 1. Souransy. S. S. Nyman, S. Haffajee, A \& Westfelt, E. (1982) "Criticil probing depths" in periodontal therapy. Jourmot of Clinicot perodomology 9, 323336.

Lindhe, I. Nyman. S. \& Karring. T. 1 1982) Scaling and rool planing in shallow pockuts.

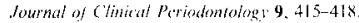

Lindhe. J., Haffajec. A. D. \& Socransky. S. S. (1983) Progression of periodental disease in adult subjects in the absence of periodontil therapy. Jounat of CWincat Periodomology 10. $433-442$.

Lindhe, J., Westfeli, L., Nyman, S. Soctansky. S. S. \& Haffajec. A. D. (1984) Long-tern

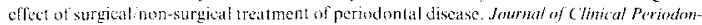
tologi 11. $448-458$

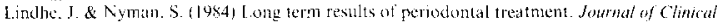
Periodemploge 11, 5144514.

L.he, H. Aanerud. A. Boysen, I1. \& Smith. M. (1978) The natural history of periodontal disease in man. The rate of perixdontal destruction hefore 40 years at age, fourmd of Piritidentritige 49, 6017-620).

Morrison, E. C., Ramfjord, S. P.\& Hill. R. W. 11980) Shori-erm eflect of initial non-setrical

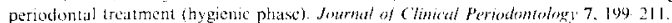

O'Leary, T. I. 1)rake, R. B., Crump. P. P. \& Allen. M. F. (197/) The incidence of recession in youmg males: A further study. Jownd of Piodonmolugh 42, 264267

Pihlstrom. B. L., Oriz-Campos. C. \& MeHugh, R. B. (|OXI) A randomized firur-year study of periodontal therapy. Jumbl of Perifdomolesy 52. 227-242.

Pihlstrom, B. L.. MeHugh. R. B., Oliphant, T. H. \& Ortiz-Campos, C. (1984) Comparison of surgicil and non-surgical treatment of periodontal disedsc. A review of current studies

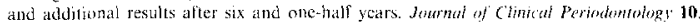
$524-541$

Prichard. J. F. (1972) Adrameex periodontal disease, 2nd edition. Philadelphic, W. B. Saunders Co.

Rabbani, G. M. Ash. M. M. \& Caffessc, R. G. (198!) The effectiveness of subgingival rout planing in calculus removal. Journal of Perisdontologl 52, $119 \quad 123$

Ramfjord. S. P. \& Nissle. R. R. (1974) The modificd Widman flap. Joursial of Poriodentoleg. 45. $601-607$.

Rosling. B., Nyman, S. \& Lindhe. J (1976) The effect of systematic plaque control on bone regeneration in infrabony pockets. Joumat of Cinical Periodonology 3, 38-53

Ramijord. S. P. \& Ash. M. M. (1979) Poriodonology and periodontics. Philadelphia, W. B. Silunders Co. 
maryuec yue leimination chirurgicale des puches et loperation i lambean de Widman modiliée. Pour kes poches de 46 mm. ke delarlage anec surtatione radiculatre et le curelage sous gingival donnaienti de meilleurs ré suhats du nom de wo de lattache que l'elimination chirurgicate des pexhes. Pour les puches de 712 mm. il n'y at wat pas de differerce statistiquement significutive enire ko resulats obtenes atec les dillorntes methories.
Sumi, I. D. et al. (197) The effect of controlled orat hygiene procedures on the progression of periodonkial discase in adults. Results after third and final ycat. Joumal of Periodonolog: 42. 152160 .

\section{Address:}

Dr. Sirund P. Ramfiom

The Uniacrity of Miching

Sithol of Dewistr

Depowisent of Periodinnicis

Ann A, hor. Michigan 4 silos

IiSA 
This document is a scanned copy of a printed document. No warranty is given about the accuracy of the copy. Users should refer to the original published version of the material. 